\title{
Research on the path of private enterprise human resource management performance based on enterprise value system
}

\section{model}

\author{
WEI Xiao-zhao ${ }^{1}, \mathrm{HONG}$ Wen-xia ${ }^{2}$, YANG Fan ${ }^{3}$ \\ ${ }^{1}$ Qingdao University of Technology, management school,china,Qingdao, Shandong \\ 266520 \\ ${ }^{2}$ Qingdao University of Technology, management school,china,Qingdao, Shandong \\ 266520 \\ ${ }^{3}$ Qingdao University of Technology, management school,china,Qingdao, Shandong \\ 266520
}

\begin{abstract}
Along with China's economic expansion, internationalization, private enterprise as a semi mature enterprise group in continuous attention. Human resource management in private enterprises have gradually become one of the important factors that must be considered in management. By reflecting existing in our country's private enterprise human resource management problems, establish the view the strategic management model of enterprise value, enterprise value, employee behavior change and strengthen the model of enterprise values of individual competency model system model, and then discussed how to establish the reasonable values of employees of enterprises to improve the management, in today's era under the direction of the establishment of private enterprises, and to improve the internal management of the enterprise performance. At the same time, as private enterprises laid a certain foundation in the future development.
\end{abstract}

Key words: Enterprise value system model, private enterprise, enterprise management performance

\section{Introduction}

The private enterprise with the economic development of our country, enterprises continue to increase, the enterprise benefits continue to improve, the direction of enterprises continues to expand, the nature of the enterprise is continuously optimized. In recent decades, the status of private enterprises should be increasingly prominent in the development of the national economy, China has become the cornerstone of economic and Technological Development and progress since. China entered a new economic era, private enterprises continue to develop and grow, from a single type of enterprise development to complex enterprises, enterprises form changes with the development of economy, enterprise content innovation, to gradually adapt to the market demand and the rapid growth of private enterprises has become an important part of the national economic growth. At present, private enterprises to create the total 
private value of goods and services in China accounted for about $45 \%$ of GDP, providing more than $60 \%$ jobs for the whole society [1-2].

Since the market economy unceasing development, the private sector increasingly fierce competition between enterprises, human resources management plays an very important role for the development of private enterprise. Human resource management system of rationality have become the lifeblood of vital importance for private enterprises. Today because of the size of the private enterprise of our country is small, the number of features and no scientific human resources management system formed the scale of the human resource management of private enterprises are due to the different nature of enterprises and different problems. In today's economy, excellent enterprise values, enterprise employee boss will be consistent behavior will provide advantageous conditions for the development of private enterprises is relatively in this paper. The disadvantages and existing leading private enterprise human resources management in the enterprise value of inquiry for the promotion of human resources of private enterprises The corresponding methods of resource management.

\section{The theoretical study of enterprise value for private enterprise human resource management}

Corporate values, as a macro concept into concrete enterprises, is a very wide range of influence. From the corporate strategy, business ideas to the corresponding products and service for the market development, staff recruitment, training, performance appraisal and so on a series of enterprise behavior and enterprise value concept plays an irreplaceable role in all aspects of daily operation of the enterprise.

\subsection{The influence of enterprise value concept on enterprise strategy and management thought}

Enterprise strategy is mainly for enterprises to develop strategic goals completed, its role is through human resource management activities to supplement, integration of human resource management of assets, so as to enhance their own advantages, make enterprises get more competitive in the market. The enterprise strategy, enterprise management thought is the process of the develop a reasonable business philosophy and management methods and strategies, improving the efficiency of direct help enterprises, promote the survival and development of enterprise vitality, thus speeding up the pace of the rapid development of the enterprise. The enterprise value is the core of enterprise ideological and initiative, through the corporate strategy and management of two parts, with the enterprise value oriented will, enterprise strategy, human resources management business combination, the appropriate economic forms in order to better development ${ }^{[3]}$.

\subsection{The influence of enterprise value on human resource management}

The difference of enterprise values in different enterprises will directly lead to different recruitment methods. Recruitment as a key step in human resource management, in many ways by the impact of corporate values. In the enterprise staff recruitment, if employees through the enterprise values of enterprises understand and identify the enterprise itself, the recruitment work is simple, also for the future 
development of enterprises laid a good foundation of the personnel. In the selection of staff, not only should pay attention to the practical application ability, but also should take into account the employee's own values is conducive to the development direction of the enterprise.

Training management is the important embodiment of the enterprise values where, enterprise through various training activities to inspire staff thinking, guide the staff the intention of thinking, heart on passing on enterprise value intentionally or unintentionally, to teach the trainees, the incentive system to stimulate employee development, and inadvertently affect employee behavior, and ultimately the formation of a unified and clear corporate values, strengthen employees' self-development capacity.

Salary management system is the important tendency of corporate values and the focal point, different enterprises due to the different nature of enterprises with different salary system, the concrete mode of the salary system need to conform to the values of enterprises under the realistic condition of the specific characteristics of and. From the above we can know, enterprise value and enterprise human resource management has a close relationship. Corporate values to the enterprise human resources management has a guide, incentive, supplement, agreement, private enterprise can through reasonable and effective enterprise value concept to improve the integrity of the enterprise human resources management performance.

\section{Existing problems of human resource management in private enterprises}

\subsection{Overall planning of human resource management}

Most private enterprises in order to save the cost of the enterprise, no for the enterprise strategy making a sound, systematic human resource management planning, staff recruitment, training, performance appraisal exist greater vulnerability, does not have plan and forecast. Repeatedly, more and more enterprises pay attention to the current development and the immediate interests, does not consider the long-term, which will lead to the passive treatment of human resource management, not the actual according to the actual needs of the enterprise were planning rationality, creates this kind of situation is the main enterprise managers not to human resources tube by systematic study, backward ideas, to act on their own ideas, eventually leading to human resource planning has large gaps.

\subsection{Not enough attention to personnel training}

Private enterprises in the training of employees on the existence of contempt, but "used to be able to use" one-sided management thinking. The main reasons are: first, the point of view of enterprise investors, in order to save the cost of business, to create the current stage under the maximum benefit, coupled with the small size of the enterprise, the lack of liquidity and other enterprises. Second, enterprise staff mobility. Private enterprises due to firm age is small, weak strength of large and medium-sized enterprises or in the competitive talent market not enough "scale" and "brand" to attract talented people, resulting in the enterprise staff generally low quality, personnel mobility. If the private enterprise to integrate the training of employees, which may become a "training base" for other enterprises, may also become a new job 
hopping. Third, the lack of formal training institutions in the private sector, mostly through the way with the master, resulting in different levels of staff technology.

\subsection{Incomplete compensation and benefit system}

Private enterprises in order to pursue the maximization of benefit of enterprises, to as much as possible small cost to obtain the highest possible profit, on the salary and welfare of staff big hands and feet, usually to a variety of reasons in arrears, the deduction of wages, not wages on time or not according to the labor contract to fulfill the promised compensation, not even to employees provide the basic social medical security.

In the current market, some of the private sector lack for "excellent staff" reward incentives, resulting in lack of employee recognition for the enterprise, low production efficiency more, cannot ease for enterprises ${ }^{[4]}$.

\section{Conclusion}

The enterprise values are private enterprises in the current market economic environment to maintain competitive advantage of important factors. Combining with China's market economic system, starting from the point of view of the private enterprise, analysis of problems existing in the development of private enterprises, proposed by setting up correct and reasonable enterprise value concept change of enterprise human resources management performance to enhance the overall capacity of the enterprise, enhance the value of the enterprise concept of research in the private enterprise performance, for future private enterprises in our country to thrive provides help.

\section{Reference}

[1]Gao Suying, Zhao Shuming, Zhang Yanli. Human resource management practices and firm performance: An Empirical Study Based on dynamic environment[J].Journal of management ,2011,07:990-996.

[2]Li Shuling, Zhang Yichi. High performance human resource management and firm performance: the mediating role of the strategic implementation capacity[J].Management world,2008,04:107-114+139.

[3]Li Fang, Yang Zhaojun, Xu Jianzhong. Study on the choice of human resource management mode of small and medium sized enterprises [J]. 2012,07:119-122.

[4]Sun Hui, Xu Yongqi. The social responsibility of the enterprise forward from the perspective of Small and micro businesses human resources management of [J]. enterprise, 2012,09:79-83.

[5]Xin Ying. Thinking about human resources management of private enterprises in China [J]. Journal of Liaoning teachers' College (SOCIAL SCIENCE EDITION), 2010,06:17-18.

[6]Shen Weijie. The human resource management of small and medium sized private enterprises [J]. economist, 2014,03:232-235. 